\title{
Monetary Policy and Income Inequality in Ghana
}

\author{
Inci Parlaktuna ${ }^{1, *} \&$ Ayuba Napari ${ }^{2}$ \\ ${ }^{1}$ Faculty of Economics and Administrative Sciences, Department of Economics, Eskisehir \\ Osmangazi University, Eskişehir, Turkey \\ ${ }^{2}$ Institute of Social Sciences, Graduate School of Economics, Eskisehir Osmangazi University, \\ Eskişehir, Turkey \\ *Corresponding author: Faculty of Economics and Administrative Sciences, Department of \\ Economics, Eskisehir Osmangazi University, Eskişehir, Turkey
}

Received: December 8, 2019 Accepted: December 24, 2019 Published: December 25, 2019

doi: 10.5296/rae.v11i4.16001ＵRL: https://doi.org/10.5296/rae.v11i4.16001

\begin{abstract}
Monetary policy, even if minimal and uncertain regarding the direction of impact, has been found to have distributional effects especially in the developed world. The purpose of this study is to determine the impact monetary policy has on income inequality in Ghana which can be a case study for a developing African Economy with independent monetary policy. Data for the period 2002Q1 to 2013Q4 is used. The study used the Impulse Response Functions (IRFs) by Local Projections methodology in estimating the degree and direction of impact of monetary policy on income distribution in Ghana. From the analysis, it is concluded that contractionary monetary policy leads to an increase in disposable income inequality in Ghana marginally.
\end{abstract}

Keywords: monetary policy, inequality, Gini Coefficient, Ghana, Sub-Sahara Africa 


\section{Introduction}

Inequality is the partitioning of society into different groups based on which different groups are accorded different rights, privileges, opportunities, responsibilities or some form of it. In 'The Republic' by Plato, inequality is justified by the noble lie which associates societal status to creation itself as in the following paragraph.

'So, god in fashioning out those who are competent to rule mixed gold in at their birth; this is why they are most honoured; in auxiliaries, silver; and iron and bronze in the farmers and the other craftsmen .......... There is an oracle that the city will be destroyed when an iron or bronze is made its guardian' (Bloom, 1968, p. 94)

This 'noble lie' was used not only to justify the status of the rulers as being ordained by the gods to rule but also to ensure that the status quo of 'born unequal' is never questioned. Some form of this noble lie could have been the underpinning philosophy of the slave trade, the holocaust and racism where it was/is thought that a particular race is supposedly made of the bronze and iron and are naturally obliged to labour for the gold race or to say the least (i.e. the gold race) should be given precedence over the bronze and iron races which are supposedly less valuable. This social stratification in status is a corollary for the inequality of rights and opportunities in education, health, gender, income, wealth, employment and all other forms of inequality imaginable.

Mention must be made of the fact that in the utopian form of the noble lie, status mobility was made to sound straight forward and meritorious allowing people of guardian parentage to become auxiliaries or farmers if they so tend out to be of an admixture of silver or of iron and bronze. In reality, however, intergenerational transfer of status particularly in political power and wealth is the norm. Feiveson and Sabelhaus (2018) found intergenerational transfer of wealth to be a key explanatory factor of wealth concentration with the transfer being directly through inheritance or indirectly through access to better education. Political power has also been seen transferred through family lines perhaps due to the grooming accomplished politicians give to their children and also through their networks. This is particularly true for African countries like Togo, Kenya and Congo where political power has been passed down from father to son with the sons perhaps only reaching those feet due to their parentage. Even though all forms of inequality are of concern, income inequality is considered one of the troubling forms of inequality of our time with the income of top earners increasing faster than the rest of the population (Ingraham, 2019).

Prior to colonialism, income inequality in what became Ghana was considerably low. However, this rose sharply during colonialism with the income Gini rising from 0.30 in 1891 to 0.55 in 1960 (Aboagye \& Bolt, 2018). This rise in inequality in Ghana during colonialism and afterwards generally has been spatial with rising incomes in southern Ghana and stagnant or at worse falling incomes in Northern Ghana due to geographical factors like climate, weather and physical resource endowment (Tsikata \& Seini, 2004). Also, the concentration of colonial missionaries and missionary activities is found by Boateng, Okoye, Amoyaw, and Luginaah (2017) to have some explanatory power regarding the observed inequality in Ghana.

It is concluded in Obeng-Odoom (2012) that the increase in urban income inequality in Ghana is attributable to the increased neo-liberal economic policies of recent times. These neo-liberal economic policies in the financial and monetary sector started with the Financial Sector Adjustment Program (FINSAP) in 1989 and culminated in the Bank of Ghana Act 2002 that declares the Bank of Ghana an inflation targeting central bank (Quartey \& Afful-Mensah, 2014) in 2002. Since 2002, the income Gini has risen consistently. Figure 1 is the income inequality 
trend in Ghana for the period 2002Q1 to 2013Q4.

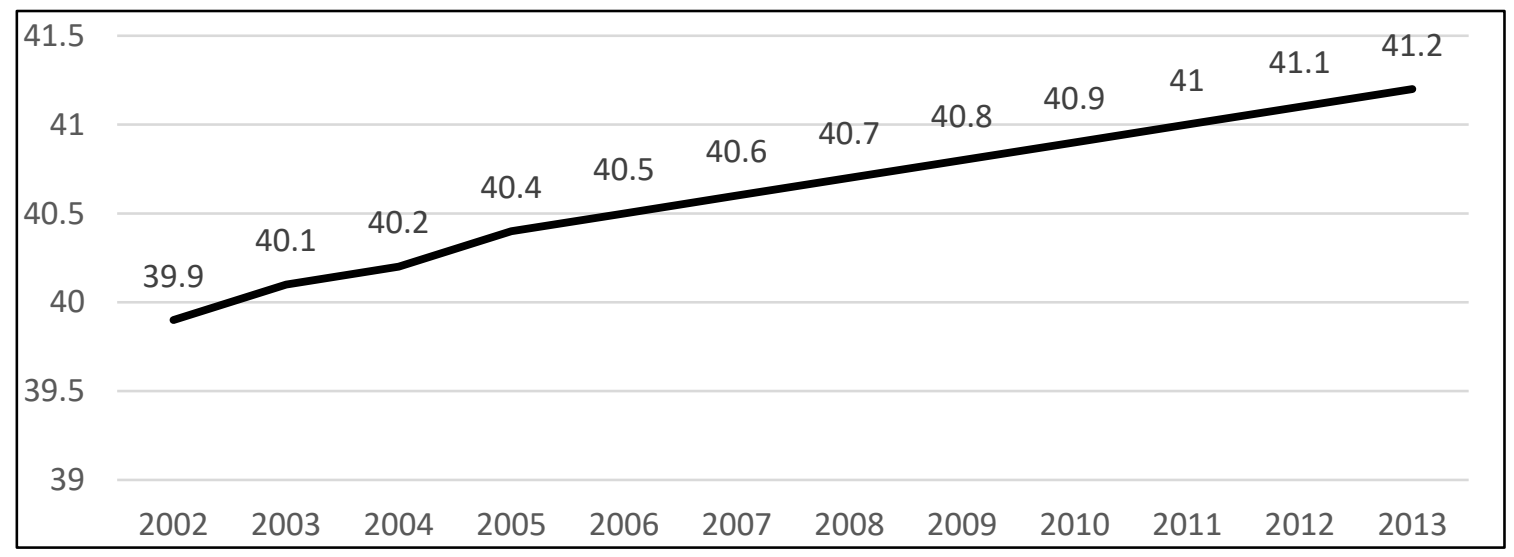

Figure 1. Disposal Income Inequality in Ghana from 2002 to 2013

The trend of inequality in Ghana from 2002 to 2013. Source: Standardised Income Inequality Database 7.1

As can be seen from Figure 1, income inequality in Ghana rose from 39.9 in 2002 to 41.2 in 2013. Beyond the spatial factors that have been identified, could monetary policy be a contributing factor to the rising income inequality? This is the object of this study. The study is structured into five (5) sections. In the first section, the general concept of inequality and some causal factors of inequality with focus on Ghana has been discussed. In Section 2, the literature on the distributional impact of monetary policy is explored. Section 3 explores the data and methodology of the study. In Section 4, the results of the study are reported and discussed. Section 5 concludes the study.

\section{Distributional Impact of Monetary Policy}

To the extent that monetary policy actions affect different economic agents differently implies that monetary policy may have unintended distributional effects (Amaral, 2017). This assertion is supported by Niggle (1989) who found evidence of monetary policy's impact on inequality through its effects on interest rates, debt to income ratios and interest income. Over-emphasis of monetary policy on inflation is argued to have caused a series of recessions which translated into high unemployment and inequality by Galbraith (1998).

Regarding the channels through which monetary policy may impact inequality, Coibion, Gorodnichenko, Kueng, and Silvia (2012) identified five (5) channels. These are the portfolio channel, the income composition channel, financial segmentation channel, the savings redistribution channel and the earnings heterogeneity channel.

The portfolio channel postulates that since low-income household hold a larger proportion of their wealth in cash whereas top income earners often hold a larger proportion of their wealth in financial and real assets. An inflationary monetary policy action will result in low-income earners losing part of their cash balances to inflation whereas top income earners who hold real and inflation adjustable financial assets might actually earn from the inflationary pressure or at worse lose nothing. This amounts to a transfer of income from low-income households to high- 
income households and thus inequality increasing.

The income composition channel is premised on the fact that there is heterogeneity across households in terms of their main sources of income. As most low-income households receive most of their incomes from labour earnings, wealthy households usually receive a larger share of their income from business and financial income. If monetary policy results in an economic expansion that leads to an increase in profits and interest income more than in wages, then those in the business and financial class will benefit disproportionately leading to an increase in inequality since they are usually the wealthy.

The financial segmentation channel correctly observes that different households have different exposure to financial markets which is the main channel through which monetary policy affect the economy. Agents who are connected to the financial markets are directly affected whereas those not connected to the financial markets are only indirectly affected by monetary policy. To the extent that those closely linked to the financial markets can act to forestall any negative impact monetary policy might have on them prior to the rest, then an increase in money supply will redistribute wealth towards these financial markets connected agents. However, since the agents who actively trade in the financial markets are the higher income class on the average, an expansionary monetary policy will be inequality increasing.

The savings redistribution channel presupposes a decrease in inequality in the face of expansionary monetary policy. Increases in unexpected inflation lower the real value of nominal assets and liabilities, making borrowers better off at the expense of lenders as the real value of nominal debts decreases (Amaral, 2017). To the extent that lenders are usually the high-income earners and borrowers the low-income earners, an unexpected decrease in real interest rates and/or unexpected increase in inflation amounts to a redistribution of savings from high-income households to low-income households.

The earnings heterogeneity channel is the other channel through which monetary policy affects inequality. Some central banks like the Federal Reserve have full employment as a complementary monetary policy target. But monetary policy affects employment and earnings differently for different categories of the labour force. As Heathcote, Perri, and Violante (2010) showed, earnings in the high-income groups are usually affected by hourly wages and that of the lower-income groups affected by hours worked and the unemployment rate. To the extent that monetary policy affects hourly wages and unemployment differently, it will produce redistributive effects (Amaral, 2017). In this regard, an expansionary monetary policy could lead to a reduction in the unemployment rate and an increase in the value of transfer payments. A contractionary monetary policy will have the opposite effect. If unemployment disproportionately falls on low-income households as it is believed to, then expansionary monetary policy will be inequality alleviating.

Empirical studies on the distributional impact of monetary policy have found contradictory results in line with the contradictory theoretical channels. In Coibion et al. (2012), Mumtaz and Theophilopoulou (2017) and Furceri, Loungani, and Zdzienicka (2018), contractionary monetary policy is found to result in increased income inequality in the USA, the UK and a group of 32 countries respectively. This contrast with the findings of Villarreal (2014) who found an unexpected contractionary monetary policy to result in decreased income inequality in Mexico. 


\section{Data and Model}

\subsection{Data}

Following the lead of Villarreal (2014), disposable income inequality in Ghana is modelled as a function of previous levels of income inequality, monetary policy, economic growth, inflation, and the real exchange rate. In addition to these variables, financial development is added to control for the possible impact of financial development and its accompanying shocks on income inequality as is found in Khan and Ssnhadji (2001) and Shahbaz and Islam (2011). As a measure of income inequality, the annual Disposable Income Gini Index $(g)$ sourced from Solt (2016); the Standardised World Income Inequality Database (SWIID 7.1), is used. The monetary policy rate ( $\mathrm{mpr}$ ) and the year on year inflation (inf) as measures of monetary policy and inflation respectively are sourced from the Bank of Ghana monetary time series database(note 1).

Like Pinkovskiy and Sala-i-Martin (2009), who used the Piece-Wise Cubic Hermite Interpolation Procedure (PCHIP) to interpolate the Gini indices for years without reported data, the Piece-Wise Cubic Hermite Interpolation Procedure (PCHIP) is used to interpolate the annual Gini indices into quarterly Gini indices. As the GDP growth rate $(g d p)$ and the Financial Development Index (find) are reported on annual frequency, the Denton (1971) temporal disaggregation method is used to transform them from the annual frequency to a quarterly frequency. This procedure is used in Islama (2014) to disaggregate annual exports into quarterly exports for Bangladesh with the disaggregated quarterly exports being as close to the actual as could be. Logs of the quarterly series of income inequality measure $(g)$, monetary policy rate $(m p r)$, financial development index (find), real exchange rate (reer), inflation (inf) and the real GDP growth $(g d p)$ are used in the empirical estimation.

\subsection{Model}

Typically, a VAR beyond feasible lag order levels will be required if the true data generating process is to be captured. This renders VAR particularly not suited when the number of observations is small (Brugnolini, 2018; Haug \& Smith, 2007). In particular, a small sample size will most likely lead to a misspecified VAR and standard Impulse Response Functions (IRFs) estimated by transforming the VAR into a Moving Average using the Wold decomposition theorem not justifiable when the data sample is small and the model cannot be said to coincide with the true data generating process (Jordà, 2005).

The IRFs by local projections is independent of a VAR system and thus immune to the problem of misspecification (Brugnolini, 2018; Jordà, 2005; Villarreal, 2014). The IRFs by local projections linearly projects the vector of variables at time $t+k$ onto the linear space generated using the information available at time $t$ (Haug \& Smith, 2007; Jordà, 2005; Villarreal, 2014). Specifically, if vector $Y_{t}=(g$, mpr, find, reer, inf,$g d p)$, then the $k$ step ahead vector $Y_{t+k}$ is estimated as in Equation (1).

$$
Y_{t+k}=\alpha^{k}+\beta_{1}^{k+1} Y_{t-1}+\cdots+\beta_{p}^{k+1} Y_{t-p}+\varepsilon_{t+k}^{k}
$$

With the $\beta_{i}^{k+1}$ being the coefficient matrices at lag $i$ at horizon $t+k, p$ is the lag order and $\varepsilon_{t+k}^{k}$ the error term. From Equation (2), the IRF by local linear projections is then defined as a function of the coefficient matrices and the experimental shock $d_{i}$ as in Equation (2).

$$
\operatorname{IRF}\left(t, k, d_{i}\right)=\beta_{1}^{k} d_{i}
$$

Noting the indifference of the IRFs by local projections to the level of integration (stationarity) 
and/or the existence or not of cointegration implies that the IRFs by local projections can be estimated without reference to the data generating process (Jordà, 2005).

\section{Results and Discussion}

The computed IRFs by local projections are presented in Figure 2. From the IRFs by local projections in Figure 2, the disposable income Gini responses to monetary policy innovations positively. This implies a contractionary monetary policy that manifest in an increase in the monetary policy rate increases disposable income inequality both in the short-run and in the long-run in Ghana. However, inequality is found to respond to financial development, inflation, real exchange rate and the GDP growth rate negatively. This implies advancement in the financial sector, increased inflation, depreciation of the local currency, the Ghana Cedi and growth in the GDP growth rate all lead to a reduction in income inequality in Ghana. The increasing effect of contractionary monetary policy on inequality by implication means a decreasing effect of expansionary monetary policy on inequality in Ghana. This results thus confirm the findings of Coibion et al. (2012); Furceri et al. (2018); Mumtaz and Theophilopoulou (2017); Romer and Romer (1999) who found monetary contraction detrimental to equality and contrast Davtyan (2016); Dolado, Motyovszki, and Pappa (2018); Ledoit (2011) and Villarreal (2014) who found contractionary monetary policy to lead to a reduction in inequality. These findings could be explained by the savings redistribution hypothesis as explained in Romer and Romer (1999). Per this hypothesis, an unexpected monetary contraction resulting in the increase of the monetary policy rate and thus increase in interest rate will result in real capital gains for households who are net creditors and real capital losses for net debtor households since loans are normally not indexed. This appeals to general intuition because low income households in the formal and informal sector and small-scale enterprises are more likely to be net debtors whereas top income households are likely to be net creditors. This means a tight monetary stance will result in reduced inflation increasing the real value of loan payments and thus transferring of capital value from the lower spectrum of the income distribution to the upper spectrum further widening the income gap.

Equally, an overly tight monetary stance might restrict government's redistribution efforts in the form of subsidies, especially of agricultural inputs and transfers which is very crucial for agricultural households in the lower spectrum (Heathcote et al., 2010) since the efficacy of any fiscal policy is dependent on the appropriate monetary stance (Keyder, 1992). The IRFs by local projections also found financial development to lead to a reduction in income inequality in Ghana. This finding confirms the results of Beck, Demirgüç-Kunt, and Levine (2007); Clarke, Xu, and Zou (2006) and Inoue and Hamori (2013) and contrast the findings of Roine, Vlachos, and Waldenström (2009) and Gimet and Lagoarde-Segot (2011) who found financial development to result in rising inequality. Kim and Lin (2011) and also Law, Tan, and AzmanSaini (2014) found financial development to only result in the reduction of inequality only after a financial developmental and institutional quality threshold. In Chen and Kinkyo (2016), it is noted that, the impact of financial development on inequality is to a large extent dependent on the quality of governance and susceptibility to crises. Tita and Aziakpono (2016) after a study of 15 African countries found the finance and inequality nexus to be nonlinear ranging from an inverted u-shape to a u-shape. 


\section{MInstitute Macrothink}
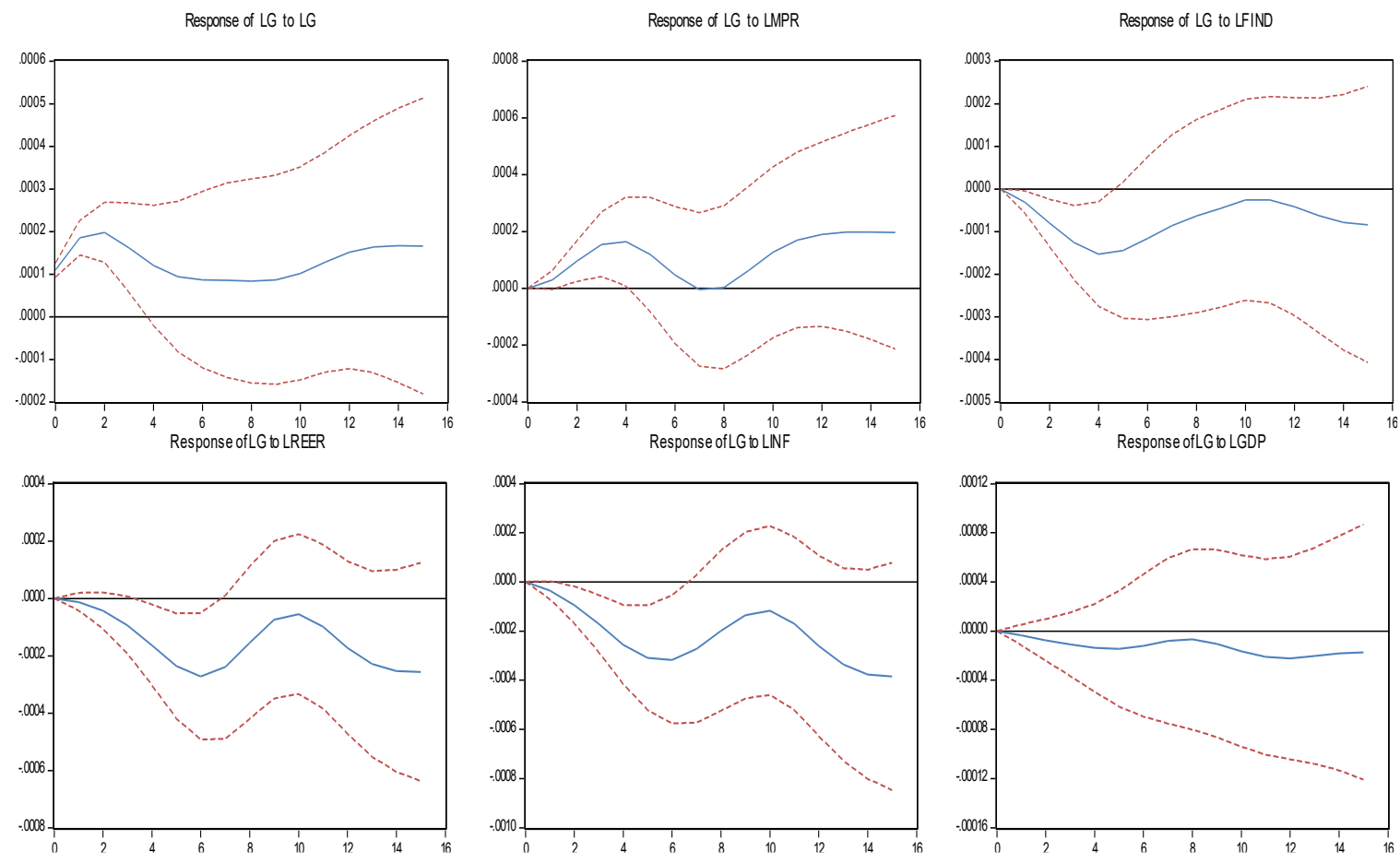

Figure 2. Impulse Response Functions by Local Projections

Response to Cholesky One S.D. Innovations 95.0\% marginal Confidence bands

Tita and Aziakpono (2016) then suggested that policies aiming at financial development should first focus on financial inclusion. The real exchange rate is found to be negatively correlated with income inequality in Ghana. This results thus lends support to the findings of Min, Shin, and McDonald (2015) who found exchange rate to be positively related with income inequality in Pakistan. The findings on inflation however contradicts that of Albanesi (2007) who found increasing inflation to result in increasing inequality. The results of this study also found economic growth in Ghana to be inclusive and thus result in a marginal reduction in inequality.

This finding contradicts that of Danquah and Ohemeng (2017) and Aryeetey and Baah-Boateng (2015) who note that, growth in Ghana is mainly due to growth in the service sector which does not impact on the lives of the lower class of the economic ladder and by implication disproportionately benefit the upper and middle classes.

\section{Conclusions}

This study sought to examine if monetary policy has any impact on disposable income inequality in Ghana using the IRFs by local projections methodology. To control for the possibility of the effects of some other variables being assigned to monetary policy, inflation, GDP Growth, financial development and the real exchange rate were included as control variables. The study used quarterly data from 2002Q1-2013Q4.

From the IRFs by local projections, it is concluded that a contractionary monetary policy resulting in the increase in the monetary policy rate results in the increase of disposable income inequality in Ghana marginally. This implies that, an aggressive inflation targeting that does not condone inflationary pressures will likely not give any monetary allowance which will lead 
to increased volatility and inequality in Ghana.

For future studies, it is recommended that several measures of inequality be used to give a clearer picture and to prevent the possible effects of data bias. Also, micro level study of the various components of household income is recommended so as to trace out the differing impact that monetary policy might have on the various components of household income.

\section{References}

Aboagye, P. Y., \& Bolt, J. (2018). Economic Inequality in Ghana, 1891-1960. African Economic History Working Paper Series, 38.

Albanesi, S. (2007). Inflation and inequality. Journal of Monetary Economics, Elsevier, 54(4), 1088-1114.

Amaral, P. S. (2017). Monetary Policy and Inequality. Economic Commentary, Federal Reserve Bank of Cleveland. (2017-01).

Aryeetey, E., \& Baah-Boateng, W. (2015). Understanding Ghana.s growth success story and job creation challenges. WIDER Working Paper Series. 2015/140.

Beck, T., Demirgüç-Kunt, A., \& Levine, R. (2007). Finance, inequality and the poor. Journal of economic growth, 12(1), 27-49.

Bloom, A. (1968). trans. The Republic of Plato. In: New York: Basic Books.

Boateng, G. O., Okoye, D., Amoyaw, J., \& Luginaah, I. (2017). Six decades after independence: the enduring influence of missionary activities on regional wealth inequalities in Ghana. Journal of Economic Geography, lby067. https://doi.org/10.1093/jeg/lby067

Brugnolini, L. (2018). About Local Projection Impulse Response Function Reliability. CEIS Working Paper, No. 440. http://dx.doi.org/10.2139/ssrn.3229218

Chen, W., \& Kinkyo, T. (2016). Financial development and income inequality: Long-run relationship and short-run heterogeneity. Emerging Markets Finance Trade, 52(3), 733742.

Clarke, G. R., Xu, L. C., \& Zou, H.-f. (2006). Finance and income inequality: what do the data tell us? Southern economic journal, 72(3), 578-596. https://doi.org/10.2307/20111834

Coibion, O., Gorodnichenko, Y., Kueng, L., \& Silvia, J. (2012). Innocent bystanders? Monetary policy and inequality in the US. NBER Working Paper, No. 18170. doi: $10.3386 / \mathrm{w} 18170$

Danquah, M., \& Ohemeng, W. (2017). Unmasking the factors behind income inequalities in Ghana. International Journal of Social Economics, 44(7), 884-899. https://doi.org/10.1108/IJSE-09-2015-0250

Davtyan, K. (2016). Income Inequality and Monetary Policy: An analysis on the Long Run Relation. IREA Working Papers, 201604. University of Barcelona, Research Institute of Applied Economics, revised Apr 2016.

Denton, F. T. (1971). Adjustment of Monthly or Quarterly Series to Annual Totals: An Approach Based on Quadratic Minimization. Journal of the American Statistical 
Association, 66(333), 99-102. https://doi.org/10.2307/2284856

Dolado, J., Motyovszki, G., \& Pappa, E. (2018). Monetary Policy and Inequality under Labor Market Frictions and Capital-Skill Complementarity. CEPR Discussion Papers, 12734, C.E.P.R. Discussion Papers.

Feiveson, L., \& Sabelhaus, J. (2018). How Does Intergenerational Wealth Transmission Affect Wealth Concentration? FED Notes, No. 2018-06-01. http://dx.doi.org/10.17016/23807172.2209

Furceri, D., Loungani, M. P., \& Zdzienicka, M. A. (2018). The effects of monetary policy shocks on inequality. Journal of International Money and Finance, 85(C), 168-186. https://doi.org/10.1016/j.jimonfin.2017.11.004

Galbraith, J. K. (1998). With economic inequality for all. Nation, 267(7), 24-26.

Gimet, C., \& Lagoarde-Segot, T. (2011). A closer look at financial development and income distribution. Journal of Banking and Finance, 35(7), 1698-1713. https://doi.org/10.1016/j.jbankfin.2010.11.011

Haug, A. A., \& Smith, C. (2007). Local Linear Impulse Responses for a Small Open Economy. http://dx.doi.org/10.2139/ssrn.1011082

Heathcote, J., Perri, F., \& Violante, G. L. (2010). Unequal we stand: An empirical analysis of economic inequality in the United States, 1967-2006. Review of Economic Dynamics, 13(1), 15-51. https://doi.org/10.1016/j.red.2009.10.010

Ingraham, C. (2019). Income inequality is rising so fast our data can't keep up: Washington: Economic policy. Retrieved from https:/www.washingtonpost.com/uspolicy/2019/02/21/income-inequality-is-rising-so-fast-our-data-cant-

keepup/?noredirect $=$ on\&utm_term $=$. a29dd $051756 \mathrm{~b}$

Inoue, T., \& Hamori, S. (2013). Financial permeation as a role of microfinance: has microfinance actually been a viable financial intermediary for helping the poor? Applied Financial Economics, 23(20), 1567-1578. https://doi.org/10.1080/09603107.2013.839859

Islama, M. R. (2014). R Program for Temporal disaggregation: Denton's Method. Paper presented at the The 2nd International Conference on Applied Information and Communications Technology - ICAICT 2014, April, Middle East College, Muscat, Oman.

Jordà, Ò. (2005). Estimation and Inference of Impulse Responses by Local Projections. The American Economic Review, 95(1), 161-182. https://doi.org/10.1257/0002828053828518

Keyder, N. (1992). Money: theory, policy, application (3rd ed.). Ankara: Middle East Technical University.

Khan, M. S., \& Ssnhadji, A. S. (2001). Threshold Effects in the Relationship between Inflation and Growth. IMF Staff Papers, 48(1), 1-21.

Kim, D. H., \& Lin, S. C. (2011). Nonlinearity in the financial development-income inequality nexus. Journal of Comparative Economics, 39(3), 310-325. https://doi.org/10.1016/j.jce.2011.07.002

Law, S. H., Tan, H. B., \& Azman-Saini, W. (2014). Financial development and income inequality at different levels of institutional quality. Journal Emerging Markets Finance 
and Trade, 50(sup1), 21-33. https://doi.org/10.2753/REE1540-496X5001S102

Ledoit, O. (2011). The redistributive effects of monetary policy. ECON - Working Papers, 44, Department of Economics - University of Zurich.

Min, H. G., Shin, S. O., \& McDonald, J. A. (2015). Income Inequality and the Real Exchange Rate: Linkages and Evidence. Annals of Economics and Finance, 16(1).

Mumtaz, H., \& Theophilopoulou, A. (2017). The impact of monetary policy on inequality in the UK. An empirical analysis. European Economic Review, 98, 410-423. https://doi.org/10.1016/j.euroecorev.2017.07.008

Niggle, C. J. (1989). Monetary Policy and Changes in Income Distribution. Journal of Economic Issues, 23(3), 809-822.

Obeng-Odoom, F. (2012). Neoliberalism and the urban economy in Ghana: Urban employment, inequality, and poverty. Growth and Change, 43(1), 85-109. https://doi.org/10.1111/j.1468-2257.2011.00578.x

Pinkovskiy, M., \& Sala-i-Martin, X. (2009). Parametric Estimations of the World Distribution of Income. NBER Working Papers, 15433. https://doi.org/10.3386/w15433

Quartey, P., \& Afful-Mensah, G. (2014). Financial and monetary policies in Ghana: A review of recent trends. Review of Development Finance, 4(2), 115-125. https://doi.org/10.1016/j.rdf.2014.07.001

Roine, J., Vlachos, J., \& Waldenström, D. (2009). The long-run determinants of inequality: What can we learn from top income data? Journal of Public Economics, 93(7-8), 974-988. https://doi.org/10.1016/j.jpubeco.2009.04.003

Romer, C. D., \& Romer, D. H. (1999). Monetary policy and the well-being of the poor. Economic Review issue, 84(QI), 1-49.

Shahbaz, M., \& Islam, F. (2011). Financial development and income inequality in Pakistan: an application of ARDL approach. MPRA paper, 28222.

Solt, F. (2016). The standardized world income inequality database. Social science quarterly, 97(5), 1267-1281. https://doi.org/10.1111/ssqu.12295

Tita, A. F., \& Aziakpono, M. J. (2016). Financial development and income inequality in Africa: A panel heterogeneous approach. Working Papers, 614, Economic Research Southern Africa.

Tsikata, D., \& Seini, W. (2004). Identities, Inequalities and Conflicts in Ghana. CRISE Working Paper, 5 (November 2004).

Villarreal, F. G. (2014). Monetary policy and inequality in Mexico. MPRA Paper, 57074, University Library of Munich, Germany.

\section{Note}

Note 1. Bank of Ghana, Monetary time series database (https://www.bog.gov.gh/statistics/timeseries-data) retrieved on $05 / 11 / 2018$ 


\section{Copyright Disclaimer}

Copyright for this article is retained by the author(s), with first publication rights granted to the journal.

This is an open-access article distributed under the terms and conditions of the Creative Commons Attribution license (http://creativecommons.org/licenses/by/3.0/). 